\title{
Attachment Theory and Religious Violence: Theorizing Adult Religious Psychopathology
}

\author{
Victor Counted \\ v.counted@westernsydney.edu.au
}

\section{Abstract}

This paper explores the ways in which attachment disruptions might increase the risk of adult religious psychopathology by drawing parallels between the possible symbolisms lying behind religious violence and the concept of attachment. It is first argued that the relationship between a religious believer and a religious figure can be explained as an attachment experience. Secondly, it is proposed that when a religious attachment figure becomes a target of slander, or an action is perpetrated to disrupt the bond with such a figure, the religious believer may be predisposed to defensive, adaptive reactions, in the form of protest, despair, or detachment, to protect their attachment bond and resolve the disruptions that threaten their religious attachment identity. Support for this theoretical proposition was obtained through discourse analyses of three case examples (Charlie Hebdo vs al-Qaeda, Boko Haram vs the Nigerian government, and Pastor Terry Jones vs Islamic radicalisation), which position attachment theory as an alternative explanatory framework for conceptualising religious violence as a form of religious attachmentpsychopathology — aimed at safeguarding the affectional bond with a religious figure from whom one may have developed a sense of identity and safe haven.

Keywords: attachment theory, defensive responses, adult religious psychopathology, terrorism, al-Qaeda vs Charlie Hebdo, Boko Haram vs Nigerian government, Pastor Terry Jones 


\section{Introduction}

Attachment theory conceptualises the provision of security by a primary caregiver to an infant as imperative for enhancing the infant's chances of survival (Bowlby 1969). This is because infants have a universal need of attachment with their primary caregivers when distressed and in need of care. As infants advance in life and become adults, future attachments may be formed with other substitute caregivers that satisfy their basic attachment needs and contribute to the development of identity (Ainsworth et al. 1978; Campbell, Adams, Dobson, 1984). As a behavioural system, attachment enables one to develop the trust, industry, autonomy, and implicit knowledge to deal with the threats to self that often accompany an identity formation process (Lapsley, Rice \& FitzGerald 1990), especially in religious situations. Research on individual differences in adult attachment processes have provided the basis for examining the relationship between lifespan attachment development and religious fundamentalism (Mickelson et al. 1997; Leonard et al. 2013), showing how followers of a religion can ascribe to an ideology because of the psychological benefits it can afford them in dealing with issues of insecurity in real life. Although most fundamentalist ideologies may be related to religious prejudice and psychological benefits (Brandt \& Van Tongeren 2015; Brandt \& Renya 2010; Wood, 2010), the extent to which such ideology and benefits are internalised and interpreted based on attachment needs remain unclear. This way of thinking about religious psychopathology as a conceptualisation of religious violence (also see Kashima 2016; Saroglou 2016), can provide some insights into the potential of examining religiousrelated conflicts through psychological lenses.

In this paper, a theoretical exploration of attachment perspective on religious psychopathology is presented with an interest in religious conflict and/or violence. Acts of religious violence are conceptualised as responses that involve a religious attachment-psychopathology that is moderated by a large scale of psychological, biological, and socio-cultural factors. Following a brief theoretical introduction of basic attachment concepts, the paper offers case examples demonstrating that re-enactments of attachment may be associated with religious violence, and that understanding the nature of attachment processes is as important as addressing the issue of religious psychopathology being discussed. This was achieved by employing a discourse analysis which ensures a constant interplay between texts (interviews with selected groups, 


\section{Victor Counted}

documents, and available literature), discourse (set of possible statements), and context (the social and historical settings of the events). Data information on Al Qaeda, Boko Haram, and Pastor Terry Jones were obtained and used as case examples for the discourse analysis since they are mainstream cases that more richly illustrate how attachment processes in religious situations can be used to explain religious psychopathology. The selected case examples were analysed based on eight-steps proposed for conducting discourse analysis: identifying a theory (conceptualising an idea of what might be happening), operationalisation (how the adapted theories translate their claims into an overall framework), sampling (analysis of three cases), collecting evidence of interviews (through online platforms and public statements by selected groups), transcribing interview statements, member check (confirming statements via a third party using available references that have analysed similar data), analysis of the sets of texts collected, and debriefing (being open to other empirical data and juxtaposing common understandings on the topic with other broader contexts) (Bondarouk \& Ruël 2004).

By employing the discourse analytical method, this paper starts by conceptualising attachment-religion aspects as the conceptual basis for explaining acts of religious violence as defensive, adaptive reactions employed in dealing with the fear of losing the attachment bond ${ }^{1}$ (with a religious figure) upon which an identity has been formed. This attachment theoretical discourse on religious violence invites scholars to consider attachment with religious figures as a mobilising bond with much broader religious implications. And thus, argues that acts of religious violence are carried out by people who are in defence of their religious figure, one that is often perceived as a symbolic attachment figure, providing a sense of comfort, security, and meaning for the religious believer. This attachment figure, as reasoned in the subsequent sections of this paper, may take the form of a divine entity, a spiritual leader, a religious figure, a religious charismatic personality, a sacred object, or sacred texts perceived as part of identity.

1 In attachment theory, 'an attachment is an affectional bond, as is the caregiving bond. Thus, [an individual] develops an attachment bond with their attachment figure and the caregiver develops a caregiving bond with the [individual]' (Prior \& Glaser 2006, p.57). 


\section{Attachment Theory and the Search for a Religious Attachment Figure}

Over the past three decades, attachment theory has been applied to understand human behaviour and how individual differences in social contexts are the product of relationships with primary caregivers. At the conception of his attachment theory, John Bowlby $(1958 ; 1969 ; 1973 ; 1977)$ sought to explain the evolutionary process that binds infants to their caregivers. He then formulated the basic tenets of attachment theory, viewing attachment as a strong, enduring emotional bond that connects two relational partners across time and space. This early contact experience with a primary caregiver forms what Bowlby calls 'internal working models' which are mental representations of self and others that influence the character of and expectations from future social relationships with attachment figures. The initial idea of attachment theory was later developed by Ainsworth (1973) and her colleagues (Ainsworth et al. 1978) who advanced the attachment framework as a system for evaluating parent-child relationships. From their Strange Situation research, Ainsworth (1973) and colleagues (Ainsworth et al. 1978) formulated three different categories of attachment styles. The first is the secure attachment style in which infants are distressed upon the unavailability of primary caregivers but comforted when in close proximity with them. The second attachment style, known as the anxious-ambivalent, illustrates how infants are greatly distressed upon the departures and return of their primary caregivers. The third pattern of attachment, anxious-avoidant, saw infants unbothered about the unavailability or availability of their primary caregivers. Main and Solomon $(1986 ; 1990)$ later identified the disorganised attachment style, a fourth pattern, in which infants seemed disoriented and confused about attachment-seeking, as they exhibited tendencies of both anxious and avoidant styles (cf. Hart, Limke, Budd 2010). Regardless of the style, Bowlby's attachment theory was developed to elucidate the

kernels of truth in Freud's insights about close relationships by replacing his image of a needy, dependent infant motivated by drive reduction with one of a sophisticated, competence-motivated infant using its primary caregiver as a secure base from which to explore and, when necessary, as a haven of safety and a source of comfort (Waters \& Cummings 2000:165). 


\section{Victor Counted}

The ability to perform the role of a secure base and a safe haven in times of distress and exploration makes a primary caregiver an important force in an infant's life, from which separation would have negative consequences that could lead to any of the insecure attachment styles listed above. Ideally, the primary caregiver provides the infant with a sense of security and awareness in their exploration of the world around them, as they develop their identity and model themselves in association with their caregiver.

Over the years, the idea of an 'attachment caregiver' or 'attachment figure' has evolved with several researchers applying the concept to mean an object of attachment that satisfies the emotional needs of infants, adolescents, or adults. In particular, Haven and Shaver (1987), and many other researchers, have demonstrated that individual differences in adult attachment processes seem to correlate with that of childhood attachments. It is on this ground that Kirkpatrick and Shaver (1990) conceptualised a theory of attachment-religion aspects in which they positioned the concept of God (as a generic term that is not restricted to any religion) as an ultimate object of attachment, arguing that attachment theory provides us with a useful framework for understanding religious belief and behaviour. The obvious starting point for the religious attachment argument is that one of the central tenets in most monotheistic religions is the belief in a personal God or religious figure (e.g. Jesus, God, Jehovah, Mary, Allah, Buddha, Brahma, Jedi, or other forms of figures in new age spiritualities) with whom the follower has a personal relationship in everyday life. The idea of having 'a relationship with God' resonates well among religious adherents when compared with other statements of faith (Gallup \& Jones 1989). Religion connotes an idea of 'being bound' with the divine (Ferm 1945), a connection that Kirkpatrick (1998) has linked to the attachment working model developed with a primary caregiver from which the individual explores future (religious-related) relationships.

Cicirelli (2004) has expanded this idea in his consideration of lifespan attachments, even though he noted that Weiss (1986) has contested such framework, arguing that attachment processes decline as infants reach adolescence and strive for autonomy. Weiss contends that infants retain their residual attachment to the primary caregiver which then continues throughout their adult lifespan in a way that makes the primary caregiver to remain an irreplaceable caregiver. However, Cicirelli (1991a; 1991b) has maintained that when adults are separated from their primary caregivers for a long period, a surrogate attachment figure emerges as part of the working model where the 
adult becomes drawn to an object of attachment that represents the primary caregiver. This symbolic attachment motivates adults to develop religious beliefs in which they perceive a relationship with God or a religious figure as a symbolic attachment - exhibiting attachment religious behaviour in the form of prayer, devotion to a sacred space, reading religious texts, rituals, and so on, to maintain the relationship (Williams \& Watts 2014; Ellison et al. 2015; Counted \& Watts 2017). This symbolic attachment is a representation of a primary caregiver who is unavailable to the individual. It is reasoned that in the view that God takes the position of a surrogate attachment in the absence of the primary caregiver, an attachment-religion connection is developed because of the role played by God as the safe haven and secure base in the absence of the primary caregiver. On this ground, it is suggested that divine entities, religious figures, or religious objects could be perceived as symbolic attachment caregivers by religious followers who perceive them as sources of support and security.

Considerable evidence supports the attachment-religion hypothesis in the study of psychology of religion (cf. Granqvist \& Kirkpatrick 2016; Granqvist, Hagekull, \& Ivarsson 2012; Granqvist, Mikulincer, Gewirtz \& Shaver 2012; Granqvist, Mikulincer \& Shaver 2010; Granqvist, Ljungdahl, Dickie 2007; Cicirelli 2004; Kirkpatrick 1992), supporting the idea that religion, in terms of having a relationship with God, fulfills both the safe haven and secure base functions of attachment processes. This way of thinking about religion in terms of believer-God relationship is rooted in the idea that adult attachment development with invisible divine entities or religious figures is possible due to increased cognitive abilities in adults (Bretherton 1987). Unlike infants who require steady physical interaction to develop attachment bonds with their primary caregivers, older children and adults have a much stronger cognitive capacity which allows them to maintain attachments through verbal and visual connections with their representative abstract, anthropomorphic figures, even in religious situations (Granqvist \& Kirkpatrick 2016). Adults can therefore depend upon the knowledge of the whereabouts of their religious figures for their attachment satisfaction. This was amplified in the work of Sroufe and Waters (1977), who argued that the goal of adult attachment is the need for 'felt security'. According to Sroufe and Waters, this need can be met in adult attachment processes, and in particular through a relationship with a religious figure who is not physically visible but felt by religious adults. 


\section{Victor Counted}

Psychology of religion researchers (e.g. Granqvist \& Hagekull 1999; Hall et al. 2009; Augustyn et al. 2016; Counted 2016a; Granqvist \& Kirkpatrick 2016) classify the individual differences in attachment-religion hypothesis into several hypotheses: the compensation hypothesis (in which an individual develops an attachment to a religious figure or to a mystical experience as a way of compensating for the emotional separation from their primary caregiver), and the correspondence hypothesis (in which the religious believer seeks attachment with a religious caregiver as a security-enhancing figure while maintaining their relationship with other human caregivers) (Granqvist \& Kirkpatrick 2016). These different classifications of implicit attachments suggest a search for a religious attachment figure and a desire to have attachment with a religious caregiver. Counted (2016a:167) describes this kind of religious aspect as a 'care-giving faith' experience in which 'the young person emphasizes the importance of needing care and emotional support in their faith experience'.

The need for meaningful symbolic attachment can be the driving force behind gaining social experiences that begin early in life and continue into adulthood. Attachment is from the cradle to the grave and is one specific aspect of a believer-God relationship, or a care-giving faith experience, with its purpose being to provide the believer with a sense of security and comfort, as in the case of a parent-child relationship experience. Hence, it is argued that the same panoply of ideas that applies to the attachment between a parent and an infant could be applied in relationships with religious objects of attachment, since the primary aim of these relationships is to develop proximity to a reliable source that can bring hope, meaning, and security in times of danger and during individual growth.

The power of attachment lies in an intermediate, abstract area of the human experience that is in-between space, in a 'transitional' world. This very phenomenon of 'in-betweenness' speaks of a transitional world of attachmentcaregiving bond, holding out the promise that needs for meaningful connection and security, despite the challenges of life, can be met (Winnicott 1953). In this transitional world, the needs for care and support are met by a 'stronger' and much 'wiser' relational other, as the human person comes to terms with who they are in connection with the relational other. The loss of attachment between relational objects in this transitional world could trigger reactionary emotions of fear and insecurity, and the possibility or risk of turning to unhealthy behavioural patterns to deal with such a loss. Attachment 
theory therefore offers a promising alternative framework for understanding how relationship problems in Winnicott's transitional world are acted out in the physical realm by externalising violence in both public and sacred spaces, as will be made clearer in the next section.

\section{Attachment Theory and Religious Psychopathology}

While the attachment bond developed with a religious caregiving figure can be positive, its loss can be the worst thing imaginable and can have a negative effect on both identity and individual security. And yet, attachment separation and/or disruption can happen again and again throughout life in varying circumstances. For some it could be the loss of an attachment figure through a tragic death, while others may experience attachment separation through caregiver unavailability or abandonment (Counted 2016a; 2016b; Howard et al. 2011; Lowenstein 2007; Liotti 2004). Cicirelli (2004:372) reasons that another important aspect of adult attachment development is 'the desire to protect the existence of an elderly mother [a primary caregiver] by providing physical care in order to preserve this unique attachment figure'. As discussed in the previous section, Cicirelli argues that a symbolic attachment in the form of a relationship with God can assume the representation of a parental attachment in which God is perceived by the individual as a safe haven and secure base in the absence of a primary caregiver.

Although God is an intangible entity believed to exist by members of a religious community, by analogy, individuals with an attachment to God would have the desire to protect their belief about the existence of God by vigorously defending or justifying this belief if challenged by outsiders. (Whether or not God actually exists independent of such beliefs is a philosophical issue and not the focus or concern of psychological studies.) (Cicirelli 2004:372).

Cicirelli's contention seems to draw some parallels with the work of Kobak and colleagues on attachment disruption and psychopathology. Drawing from Bowlby's (1973) Separation volume in his trilogy on attachment theory, Kobak, Zajac, and Madsen (2016) developed an attachment theoretical model for understanding psychopathology in which they suggested that the monitoring of the caregiver's whereabouts and their physical proximity to a 


\section{Victor Counted}

receiver of attachment is an expanded view on attachment processes. Kobak and colleagues (2016:26) reason that this theoretical development accounts for the contribution of attachment processes to personality development, psychopathology, and defensive processes which shift 'attention from observing reactions to separations to observing patterns of emotional communication in [individual-caregiver] dyads'. Their argument was based on the premise that saw emotionally attuned communication in attachment processes as the central fulcrum for maintaining secure attachment bonds. In other words, reactions to prolonged separation from an attachment figure would imply that the central goal of the attachment system is the monitoring of caregiver proximity and responsiveness (Sroufe \& Waters 1977). Empirical observations from Bowlby, Roberton, and Rosenbluth (1952) and Ainsworth (1962) show that infants, for example, monitor the responsiveness and availability of their caregivers, especially their ability to support, protect and provide for them during moments of danger and distress.

Bowlby and colleagues (1952) share the story of a 2-year-old girl who spent 8 days in hospital away from her mother for a minor operation. However, throughout the time of her separation experience, the little girl Laura was observed fretting and displaying separation anxiety while monitoring the responsiveness of the mother. This observation of reactions to attachment separation later provided the context for exploring how the displays of 'protest', 'despair', and 'detachment' had to be interpreted as emotional signals that suggest how attached individuals 'monitor danger in the environment, explore new learning opportunities, and... social exchanges' (Kobak, Zajac \& Madsen 2016:27). In the later pages of their chapter, Kobak and colleagues conceptualised separation experience as a form of 'attachment disruption' in which responses to it can be analysed in terms of protest, despair, and detachment, which were positioned as the three phases of infants' defensive reactions to prolonged separation from a caregiver.

According to Kobak and colleagues, the protest phase starts the moment the caregiver switches off communication with the infant, which sees infant signaling their separation distress through crying loudly, following the caregiver, showing anger, or pounding the door, as seen in the observation of Bowlby, Roberton, and Rosenbluth (1952). At the first phase, the child is optimistic about having the caregiver back while displaying dominant emotions such as fear, anger, and distress. However, in the despair phase which succeeds protest, the infant is most likely to be withdrawn. At this phase 
the infant interprets the separation experience as a loss of the attachment figure (Kobak, Zajac \& Madsen 2016), showing what Bowlby (1973) calls 'deep mourning', and in some cases showing signs of sadness and agony. Heinicke and Westheimer (1966) reasoned that it is also possible to observe hostile behavioural patterns, directed toward other kids or things that reminds them of the caregiver, during this second phase of defensive reaction. Detachment marks the final phase of the defensive mechanism to which the infant shows positive attitudes toward alternative caregivers as a way of surviving in the environment. Bowlby (1973) describes these defensive processes as the ethological approach to human fear, highlighting how prolonged threats and disruptions to caregiver proximity could contribute to negative interpersonal expectancies and anxious attachment patterns which are internalised as working models that increase the risk of adult psychopathology. Kobak and colleagues corroborate this knowledge paradigm, reasoning that the disruption of attachment processes and threats to caregiver proximity can have significant impact on the individual person. Solomon and George (2011) conducted similar studies on caregiver responsiveness and disorganised attachment, describing the response of the infant to the prolonged failure of their caregiver responsiveness as caregiver abdication. The concept of caregiver abdication was used to describe the breakdown in the attachment bond that includes frightening and starving the infant of attachment and the response of the infant to a failure to protect them. The concept of caregiver abdication can be applicable to the concept of attachment disruption and psychopathology, especially in cases where the individual is reacting because of threats to caregiver sensitivity and responsiveness. Caregiver abdication in adults can also be portrayed in a religious attachment relationship by defending the religious figure from perceived harm or threats of attachment disruptions.

Attachment disruptions are 'prolonged or severe threats to a caregiver's availability or responsiveness that create fundamental fear and uncertainty about the caregiver's availability or capacity to respond in moments of danger' (Kobak, Zajac \& Madsen 2016:28). When such disruptions are not addressed or remain unrepaired, the individual may become vulnerable to persistent feelings of anxiety, fear, sadness, and anger; thus, developing defensive, reparative strategies and prejudices in the form of protest, despair, and detachment that serve to restore confidence in the attachment bond. These defensive processes also reduce 'the individual's 


\section{Victor Counted}

ability to engage in emotionally attuned communication with caregivers' ( $\mathrm{p}$. 28). Kobak and colleagues view this emerging perspective as a paradigm shift in attachment research which shifts focus on children's separations from parents to more broader investigations that examine the quality of emotional communication in adult attachment processes. Attachment theory provides a blueprint for understanding how stressful moments in the form of attachment disruptions or separation experience can predispose a person to elicit dysfunctional emotional defenses and responses that are only symptomatic expressions of the need for attachment proximity and desire to resolve threats to the attachment bond (Kobak, Zajac \& Madsen 2016).

In extension, it is argued that threats to the attachment bond in a relationship between a religious believer and a religious figure can initiate defensive processes that aid in coping with the reality of religious attachment disruptions. Hence, disrupting the attachment processes in relationship experiences with religious attachment figures may as well become the genesis of adult religious psychopathology, especially in aspects of religious violence that are often interpreted as protest, despair, and detachment. There are two main reasons for this assumption. Firstly, because the attachment system is one that is emotionally attuned to monitor the availability and proximity of the (religious) attachment figure. Hence, in a situation where a relationship with a religious figure is under threat, or the emotional bond disrupted, this separation experience may initiate reparative, defensive processes that are motivated by a desire to re-establish closeness with the religious figure and restore confidence in the relationship. Secondly, an attachment theoretical perspective on religious violence is proposed because differences in identity development are often formed based on attachment expectations. Several studies have shown evidence of our second assumption on the relationship between emotional attachment and identity status (Campbell, Adams, Dobson 1984; Berzonsky \& Neimeyer 1994), supporting the conceptualisation of identity as a psychosocial, attachment development (Erikson 1956). Studies suggest that individuals with secure attachments show a willingness to construct their identity based on the values of those around them, particularly their attachment figures, whereas those with insecure attachments tend to procrastinate in the process of identity formation. Identity can be interpreted in terms of emotionally attuned communications in attachment dyads as the receiver of attachment models their identity based on the values of the caregiver, as evidenced in the work of Berman and colleagues (2004; 2006). 
A religious follower is likely to model their identity and perception of self based on the values of the religious attachment figure to whom they are devoted. For example, a Christian is likely to model the life and teachings of Jesus Christ. The same way a devout Muslim may form his or her identity based on the teachings of Prophet Mohammed. Hence, at moments of attachment disruptions with the religious figure, the religious believer may become predisposed to defensive strategies that eliminate the possibility of losing their identity and the attachment bond with the religious figure. This can come in the form of desiring to hold on to the feelings of security and identity that they have in their religious figure or in their religious beliefs in order to achieve happiness and maintain their secure attachment bonds. Thus, identity becomes embedded in the relationship with the religious figure or to whatever sacred object that represents a connection to such mystical experience. If identity is shaped around a religious attachment figure, then the natural response is to defend it and maintain the attachment bond with such an object. To do so, Soltis (1983) reasons in his 'exploitable weakness principle' that there is benefit in exploiting the weakness of the opposing force which is seeking to disrupt the bond that has been developed with such a significant object. As a result, a protective force is formed around the object of attachment as arguments in support of the object are put forward on its behalf to defend it (Ruiz 2013).

It is reasoned then that when a religious figure is experienced as a safe haven the individual may turn to such a figure for protection, wisdom, or hope in times of danger the same way a child would run to a mother for such affordances. However, when a religious figure is perceived as a secure base the individual may represent themselves or explore the world based on how they see the figure. In these two scenarios, the religious figure becomes an object for identity formation and for exploring the world; the same way a child would look up to a primary caregiver to frame the way they see themselves and the environment. When a religious attachment figure becomes a reliable safe haven and secure base, much is needed to guard this unique experience. An object of attachment is easily recognised as such, especially when there is the fear of losing it. The fear of losing an attachment can be associated with an individual's internal working models and the extent to which such individual can manage attachment insecurity. This varies from person to person and often has a lot to do with how a primary caregiver was experienced. The possibility of change may make it impossible to hold on to a particular 


\section{Victor Counted}

attachment object or caregiver for a lifetime. Change is a fact of life: relationships may end, friends may be lost, faith may fade, places of belonging may be abandoned, old age advance, a loved carer may die, and so forth. Evaluation of objects of attachment provides an indication of the identity shaped around them. The fear of losing the attachment bond and identity with a religious figure can cause extreme reactions in some religious believers, as they fight to both defend and protect that which means much to them.

People are likely to defend their objects of attachment because their identity is shaped by the objects. This, I believe, is what members of militant religious groups do when they claim allegiance to religious figures that are representations of their symbolic attachments. It is not only the figures that they are defending but also their own attachment identity. Thus, religious violence may be interpreted on the one hand as defending an attachment identity that has been formed through a religious figure, and on the other, securing the attachment bond with a religious figure that is under attack. Hence, these two interpretative pathways may be the mechanisms linking religious violence to adult attachment-psychopathology. Having established that an individual can develop an attachment bond and identity with a religious figure who is perceived as being a haven of safety (one to whom they turn to in times of distress) and a secure base (one from whom they develop identity and explore the world of danger), what then can be said about the forces that might seek to destroy such a bond? Should such forces be perceived as a threat by the recipient of the caregiving? If so, is the establishment of a protective defence mechanism against these forces justifiable, given that the fight is one of identity, and failure to protect it could mean losing sense of self? In order to challenge the way we think about religious violence, the subsequent paragraphs will build up on the already established arguments, while also drawing on empirical insights to elucidate and clarify the theoretical propositions on religious attachment-psychopathology.

\section{Case Examples of Defensive Responses to Religious Attachment Disruptions}

Although it is reasonable to see religious violence as a struggle between two conflicting groups, it is also important not to ignore that the subliminal grievances of protest, despair, and detachment on the part of the perpetrator could be because of the interpretations provided in the previous section. Adult 
religious psychopathology in terms of religious violence has been conceptualised as defensive responses arising, over time, due to the fear of losing an attachment bond and the identity developed thereof. In the next sections, three case examples are used to illustrate the problem of religious violence from the perspective of the perpetrators as a vulnerable group, defending and protecting their objects of attachment from which they experience a safe haven and secure base.

\section{Charlie Hebdo versus the Al-Qaeda Islamic Group}

Charlie Hebdo is a controversial and nonconformist newspaper known for featuring cartoons, reports, and jokes reflecting the magazine's irreverent, antireligious stance on sensitive issues that often make fun of Catholicism, Islam, Judaism, and various other institutions while at the same time sharing local and international news. Charlie Hebdo's cartoonists are widely celebrated for attacking political and religious institutions without mercy, often crudely. The senior editor of Charlie Hebdo, George Biard, once said that 'Attacking all religions is the basis of our identity' (Murray 2015). In 2006, several Islamic organisations sued the Charlie Hebdo newspaper for re-publishing the Jyllands-Posten (a Danish newspaper) caricature of Muhammad, but they were unsuccessful. Charlie Hebdo published a similar satirical cartoon of Muhammad later in 2011, which according to some was a forbidden depiction of the Islamic religious figure in some interpretations of Islam (cf. BBC News 2011). In response, the newspaper was firebombed and attacked; their website was also hacked (Boxel 2011). This protest phase continued between the news agency and the Islamic communities who were against the satire of their religious figure with placards saying 'Behead those who insult Islam', 'The future must not belong to those who slander the prophet of Islam', 'Be prepared for the real holocaust', and 'Freedom go to hell', among others. In 2012, similar publication made its way again to public light via Charlie Hebdo, this time, publishing several cartoons and nude caricatures of Muhammad. This came at a time when there were several attacks on the United States' foreign missions in the Middle East. Vinocur (2012) believes that these attacks were linked to the anti-Islamic film 'Innocence of Muslims' which spurred outrage across Islamic states, hence prompting the French government to close their embassies and foreign missions in several Muslim countries (Samuel 2012). As the cartoons of Muhammad sparked debate and riots within Muslim 


\section{Victor Counted}

communities in France and around the world, riot police surrounded the Charlie Hebdo's offices to guard them against possible attacks. The intensity of the Muslim community outrage from around the world, at this point, could be conceptualised as the despair phase of their defenses as most of them seem to exude frustration resulting from losing hope of redeeming the integrity of their sacred figure, and thus came the Islamic militant al-Qaeda group threatening to revenge for the attack on their religious figure.

In response to the accusations of Islamophobia, the chief editor of Charlie Hebdo, Stephane Charbonnier, stated in 2011, 'We have to carry on until Islam has been rendered as banal as Catholicism' (Murray 2015). In their despair, this response made the al-Qaeda militant group to add Stephane to their Most Wanted List in 2013, along with three other Danish newspaper staff members who caricatured Prophet Muhammad in earlier publications. In the early morning of Wednesday 7th January 2015, Charlie Hebdo was attacked by the al-Qaeda group, killing the chief editor Stephane Charbonnier and several other staff members. This tragic event sparked global debates over freedom of speech and Islamophobia, stressing the possible motive of the attackers, which some argued was to shut down a news agency that lampooned their religious attachment figure. In an online video response to the terror attack, Nasr al-Ansi, a top ranking al-Qaeda commander issued an official statement on behalf of the terrorist group citing 'vengeance for the prophet' as the reason for the attack.

We, al-Qaeda in the Arabian Peninsula (AQAP), claim responsibility for this operation as vengeance for the messenger of Allah ... The leadership of AQAP was the party that chose the target and plotted and financed the plan ... It was following orders by our general chief Ayman al-Zawahiri ... The heroes were chosen and they answered the call ... Today, the mujahideen avenge their revered prophet, and send the clearest message to everyone who would dare to attack Islamic sanctities (Nar al-Ansi 2015).

Gruber (2015) reasons that the Charlie Hebdo attackers were misinformed about the view that images of Muhammad are banned in the Koran. The notion of prohibition of Muhammad's images gained ground among Islamic fundamentalist groups, even though it was only intended to discourage Muslims from practicing idolatry (Burke 2015). Nonetheless, while it is 
necessary to debate what might have caused the provocation of the Islamic militant community, one can see that the caricature of their religious figure was not perceived as a friendly gesture, but rather was seen, as Nar al-Ansi puts it, 'an attack on Islamic sanctities' and a threat to undermine their source of attachment and Islamic identity. The slander of a religious figure, as seen in the case of Charlie Hebdo and al-Qaeda, is an example of how a caricature of an object of attachment, to which a group turns to for the construction of their identity, can trigger negative, defensive emotions and prejudices in the form of protest and despair toward others, arising both because of identitythreat and threats to a safe haven and secure base. One could argue then that the final stage of defensive responses to attachment disruptions, which is the detachment phase, was not observed in the al-Qaeda and Charlie Hebdo case example. Observing for detachment would mean that the religious believers show positive attitudes toward alternative religious 'caregivers', in this case turning to another religious figure, as a way of surviving and coping with the attachment disruptions.

\section{Boko Haram versus the Nigerian Government}

Boko Haram is another Islamic militant group in northern Nigeria that claims to pursue the aim of establishing a pure Islamic state in Nigeria, one that is governed by Sharia law (Walker 2012). This kind of rhetoric is like that used to disseminate the Jihadi agenda by militant Islamic groups such as Al-Qaeda, ISIS, and al-Shabaab; all of which are willing to protest in despair to defend the cause of their religious figure even at the expense of their own lives. While this pursuit is questionable in all its formulations, one cannot turn a deaf ear to the killings of innocent people by the Boko Haram group in many northern parts of Nigeria. Unfortunately, northern Nigeria has a long, sad history of riots and communal conflicts and outbreaks of religious violence between different groups, in particular among the Christian and Muslim populations, and between the Hausas and Fulanis (Agbiboa 2013). Although the trend of communal conflicts seems to be a common practice in northern Nigeria, the affliction brought to several northern states by the Boko Haram group took the world by surprise. Outside observers have now begun to take Boko Haram seriously with the awareness campaigns such as the \#BringBackOurGirls movement that drew international attention to the mass killings and abductions of innocent communities in northern Nigeria. 


\section{Victor Counted}

Despite the increased insurgency by the Boko Haram group, there has been little explanation as to what might have caused this rise in violence. Some have settled for conspiracy theories suggesting that this is a power tussle to make governance difficult for the former President Goodluck Jonathan (2010 - 2015), who was from the southern region. Within this purview, Mustapha (2014) reasons that Boko Haram could have been responding to alleged political marginalisation of Northerners. Others associate the insurgency and rise of the group to be because of poverty in northern Nigeria, and a connection to Al-Qaeda, as often described by former Nigerian President Jonathan as 'an Al-Qaeda of West Africa' (Irish 2014; Mustapha 2014). None of these theories seem to adequately explain the intentions of the Boko Haram militant group, nor why they would advocate for an Islamic state system.

It is difficult to say what drives the Boko Haram group if their motives are not examined. The history of Boko Haram is an ambiguous one, and no one account is sufficient to clearly paint a picture of what is happening within this group. However, a helpful start would be to interpret the ethos that informs about what the Islamic militant group stands for. In 2011, Boko Haram came up with a statement of belief that can help us understand their ideology and demands in relation to attachment theory, as they identified themselves thus:

We want to reiterate that we are warriors who are carrying out Jihad (religious war) in Nigeria and our struggle is based on the traditions of the holy prophet. We will never accept any system of government apart from the one stipulated by Islam because that is the only way that the Muslims can be liberated. We do not believe in any system of government, be it traditional or orthodox, except the Islamic system which is why we will keep on fighting against democracy, capitalism, socialism, and whatever. We will not allow the Nigerian Constitution to replace the laws that have been enshrined in the Holy Qur'an, we will not allow adulterated conventional education (Boko) to replace Islamic teachings. We will not respect the Nigerian government because it is illegal. We will continue to fight its military and the police because they are not protecting Islam. We do not believe in the Nigerian judicial system and we will fight anyone who assists the government in perpetrating illegalities (Salkida 2009).

From the above statement, it appears that the Boko Haram group seems to 
identify themselves as some sort of 'defenders' of the Islamic identity in their protest and despair. There seem to be an underlying bond with their faith and what it represents to them, and anyone who stands contrary to this sense of identity or pose a threat to their attachment identity will be targeted as the enemy. This form of defense seems to share similar characteristic with the Charlie Hebdo versus al-Qaeda case, where an obvious satire toward a religious figure gave rise to a negative prejudice and reactionary defensive responses of protest and despair that ended up in horrific terror attacks. In the case of Boko Haram, the terror group felt threatened by a new government which they claim might enforce the state constitution to 'replace the laws that have been enshrined in the Holy Qur'an' (Salkida 2009). It seems that Boko Haram also exhibits elements of defensive processes of protest and despair just as their al-Qaeda counterpart. Unfortunately, these defenses are demonstrated through their records of killings and attacks based on an alleged accusation of attachment disruptions.

In clarifying the defensive responses of Boko Haram, Agbiboa (2013:4) considers the group as a 'movement of restoration since their overriding goal continues to be the enforcement of Sharia [Islamic law] in the spirit of earlier times'. The term Boko Haram, aside its literal meaning (i.e. Western education is forbidden) implies some sort of resistance and rejection to 'imposition of Western education and its system of colonial social organisation, which replaced and degraded the earlier Islamic order of the jihadist state' (Isa 2010:332). Isa reasons that the system represented by those who have undergone western forms of education is considered secular and corrupt by Boko Haram, and therefore has no connection to their Islamic identity. Boko Haram leader, Mohammed Yusuf, once said, 'Our land was an Islamic state before the colonial masters turned it to a kafir (infidel) land. The current system is contrary to true Islamic beliefs' (Salkida 2009). The system Mohammed describes is one that he believes is mixed with issues that are contrary to Islamic beliefs and therefore constitutes a problem to their attachment bond and identity.

While the different motives that might have given rise to the Boko Haram insurgency are put into consideration, it must also be noted that this group was a relatively small protesting fundamentalist group until the arrest and killing of their leader, Mohammed Yusuf, by the Nigerian security forces in 2009 (Umar 2011). Shortly after the killing of Mohammed Yusuf, there was a volcanic eruption of the Boko Haram despairing venom on the Nigerian 


\section{Victor Counted}

state, as they began to firebomb several strategic spots in the country to take revenge for the death of their leader and reinforce their attachment allegiance to him. Although the actions of Mohammed Yusuf might not depict the image of a typical religious figure to an outsider but he was, to some extent, a source of inspiration to those that followed him, especially among the impoverished and alienated members of Boko Haram 'who were animated by deep-seated socio economic and political grievances, such as poor governance and elite corruption' in the country (Agbiboa 2015:146).

When viewed from the outside, it appears that the demand of Boko Haram for an Islamic state devoid of Western culture has to do with religious differences and tensions between blocs of Muslim and non-Muslim groups. Far from it, I argue that the Boko Haram group appears to be protecting their objects of attachment, whether it is their sacred book (Koran) or their group's religious and/or political figure (in the person of Mohammed Yusuf), to which they have forged their sense of identity and found a haven of safety.

\section{Pastor Terry Jones and the Islamic Invasion of the West}

The interpretation of attachment-religion connection in relation to religious violence is not peculiar to any religion. Similar patterns of defensive processes to attachment disruptions seem to take center stage within Christian circles as right-wing conservatives defend and protest for the cause of Christianityeven to extreme proportions, and often seeing pacifism as an illusion indulged by Christians whose own safety is protected by non-pacifists. A good case example to illustrate how adherents of the Christian faith may also resort to similar protest on the basis of protecting identity or defending an object of attachment is the story of Pastor Terry Jones who between 2010 to 2013 planned on publicly burning 2,998 Korans to mark the anniversary of the 9/11 attacks and protest the Islamic invasion of the West. In his own words during a CNN interview, Jones warns the United States government to 'Stop Islamic migration. They are only coming to this country to enforce ... their Islamic laws upon us. We should stop the building of all Mosques in America until they allow us to build churches in Saudi Arabia and Iran' (Jones 2010). In the interview, Jones also noted that his intentions were to,

send a message to them that radical Islam, Sharia Law, or what they wish to institute for a period of time is not accepted in America .... 
We also want to send a message to the moderate Muslims to stay peaceful and moderate ... but we do not want, as it appears to be in some parts of the world, after they gained some numbers in the population they begin to push for Sharia Law and that type of government ... we expect the Muslims that are here in America to respect and honour and obey and submit to our constitution (Jones 2010).

Jones' fear of an Islamic invasion may have given rise to his defensive protest to burn that which he translates to be a threat to his safe haven and secure base in terms of his Christian faith and his country America. The rationale for wanting to burn hundreds of Korans, according to Jones, was to demonstrate that Islam was a threat to him, his Christian beliefs, and country. This example also makes an interesting case for our theory in terms of how defensive responses to attachment disruptions in the form of protest may be used to explain similar acts of religious violence from within the ranks of the Christian faith and in other cultural contexts. It is reasoned that Jones' pretext for burning the Koran also parallels with the reasons why Muslim extremists protested the Charlie Hebdo's caricature of prophet Muhammed and equally seems to have semblance with the statement of Boko Haram, even though they took it a bit far by taking human lives in their despair phase of defense. However, it seems that Jones' case only demonstrates the protest defensive phase in which the individual signals a potential separation distress due to threats to the attachment bond, be it in the form of raising placards, slogans, threatening an oppressor, or burning that which is sacred to the disruptors. Pastor Jones' case is an example of this moderate demonstration since his defenses did not escalate to that of despair which could have translated to extremities that are life threatening, as in the two previous case examples. This goes to show that despite the reactions to the fear of losing a symbol of safety and an attachment identity in religious situations, attachment disruptions can be managed at the protest phase, without escalating to the extreme despairing phase that may endanger the lives of others.

\section{Toward an Attachment-Psychopathological Theory of Religious Violence}

In the preceding pages, it was demonstrated that members of a particular 


\section{Victor Counted}

political or religious group can develop a collective drive to defend their sense of identity and protect the bond they have established with an object of attachment or religious figure through their protest, despair and detachment mechanisms. When the bond between a religious follower and a religious figure comes under the corrupting influence of another group or is perceived to be under attack (as seen in the cases of Charlie Hebdo vs al-Qaeda, Boko Haram vs the Nigerian government, and Pastor Terry Jones vs Islamic radicalisation), this experience can activate adaptive, defensive reactions and responses. This form of defensive mechanism is developed as a strategy for dealing with the tension associated with losing the attachment bond with a religious figure (Kobak et al. 2016), and thus conceptualised as the attachmentpsychopathological interpretation of religious violence. This attachment behavioural pattern is similar to Ainsworth et al.'s (1978) anxious and avoidant attachment styles in that it is a direct response to caregiver's responsiveness, as the individual develops feelings of insecurity by being fearful of others and develop self-nurturing behaviour to avoid others so as to cope with troubling emotions. In contrast, this defensive mechanism is not a secure attachment but rather an insecure pattern of attachment which might also be another way of interpreting Main and Solomon's (1990) disorganised attachment since it exhibits a bit of ambivalent and avoidant tendencies toward other groups, since the defender of the caregiver is both distrusting and dismissal of others due to the prejudices they have about them, and thus, developing defenses of protest, despair, and detachment.

A defensive attachment mechanism in the form of protest, despair, or detachment is the direct response to forces and systems that disrupt an attachment process, especially when such forces are perceived to threaten the attachment bond binding relational partners. Although it is easier to focus on the intensification of feelings and conflicts that give rise to violent religious acts as the cause of the problem, it is reasoned that this assumption is only 'to scratch the surface' and not enough. Religious violence is not always about religion, even though religion may serve as the mobilizing identity. There is a need to pay close attention to the internal conflicts, sustained attachment injuries, psychopathology, and attachment needs of the perpetrators carrying out the acts of violence to better understand how defensive responses against an opposing group can be by-products of how the human brain processes perceived threats, emotions, and worldview defense (cf. Johnson et al. 2012). Most importantly, there is also a lot to benefit from examining the nature of 
this defensive attachment that has now been proposed and how it aligns with other broader perspectives of religious violence theory.

In the case where the individual or group is at the first phase of protesting for their attachment bond due to a phenomenon of attachment disruption, such individual or group could exhibit dramatic demonstrations that only signal a potential separation distress. This distress may be because of not being able to monitor the emotionally attuned communication with the attachment figure, even though they may still be optimistic about having the figure back in their lives. However, when such disruption is severe and prolonged it can initiate the second phase of defensive reaction which is the despairing stage in which the individual or group loses hope of maintaining their attachment bond and thus putting their own lives on the line to revenge for their lost attachment. This second phase is where acts of extreme violence and terrorism are adopted to make a statement about the hopelessness of losing an attachment bond upon which identity is formed, as the individual or group becomes alienated from their true values to perpetuate horrific acts of terror and violence. In contrast, the detachment phase presents an opportunity for dialogue and exploring alternative attachment figures that would fill in the void of attachment. In inter-religious contexts, this is where the individual who has experienced severe attachment disruptions with a religious figure turns to another religious figure for answers and hope. For instance, after exhausting the first and second defensive options, a Muslim agitator could find hope and peace in another religious attachment figure within or outside of his or her own religion as a way of expressing the last phase of defensive response detachment.

Instead of shying away from the problem of attachment disruption by morphing into anxious-ambivalent or anxious-avoidant attachment style as in the case of infants, defensive processes in religious attachments demonstrate how adults experiencing attachment religious relationships defend their religious figure and respond to forces that might want to break the bond shared with their sacred objects. Agents of disruption in attachment processes are often identifiable due to a variety of factors that contribute to the development of prejudice in a person such as one's internal working models and relationship experiences, which predetermine the extent to which an opposing force is seen as an attack. Thus, adults who had unhealthy attachments with their primary caregivers would often be quick to initiate their defensive attachment mechanism as they almost immediately interpret the actions of others as a 


\section{Victor Counted}

threat to their sense of identity and attachment. It is therefore plausible to put forward that religious violence can arise from attachment insecurity due to the need to secure an attachment bond and defend an object of attachment around which a sense of identity and security has been built. Hence, it is proposed that religious violence could be conceptualised as a way of dealing with what is happening in the human minds in terms of emotionally attuned detections of attachment disruptions that make religious believers susceptible to vulnerable defenses of protest, despair, and detachment, which are initiated to secure the attachment bond being formed with a religious object.

When a group finds a haven of safety in a religious object or in a person, it should not come as a surprise when they defend their source of security and identity, especially when such a figure, or the bond thereof, is being threatened by another group. That some perpetrators of religious violence attack another group in retaliation for their external imposition to or disruption of their way of life is a theoretical perspective that could be used to further conceptualise religious violence as an attachment phenomenon. The case examples of Charlie Hebdo versus al-Qaeda, Boko Haram versus the Nigerian government, and Pastor Terry Jones essentially depict a picture of what adult defensive responses to religious attachment disruptions may look like in real-life situations, as the individuals and groups involved carry out acts of violence to defend their religious objects of attachment. These protesting and despairing groups portray themselves as defenders of a religious figure to which the security and identity of their community are framed.

There are several other broad theoretical perspectives that also point to this proposed attachment-psychopathological perspective on religious violence. Giddens (1990), for example, refers to this form of defensive responses as necessary adaptive reactions for attaining, what he refers to as an 'ontological security', which is an emotional phenomenon rooted in the unconscious. When one's sense of ontological security is threatened, the individual develops adaptive reactions to deal effectively with the challenges of being in the world. Huntington (1996) on the other hand saw this paradigm of disruption as the clash of civilisations, predicting that the dominating source of conflict would be the clash of culture of which religion is a mobilizing factor. Neumayer and Plumper (2009) also reasoned that acts of religious violence and terrorism do not necessarily depend on the prevalence of the disruptions as such, but on the strategic benefits of exploiting the weakness of an opposing group. Ultimately, when the relatively long-enduring bond 
between a social group and their object(s) of attachment is disrupted and violated, there is bound to be consequences since the object is important as a unique symbol and is interchangeable with no other (cf. Ainsworth 1973; 1989).

One obvious limitation of this paper is in the choice of three case examples which might be a potential weakness for the discourse analysis. While this might be a good critique of this paper, Georgaca and Avdi (2011:148) contend that 'discourse analyses often rely on relatively small numbers of participants and/or texts, in part due to the fact that analysis is very labour-intensive and large amounts of data would be prohibitive'. In addition, due to the individual differences in psychological functions, it is likely that the presented propositions may not be representative of every case of religious violence since research in adult religious psychopathology remain uncharted waters. Hence, more empirical investigations are required to strengthen the attachment theoretical argument on religious violence, especially ones that would represent the three defensive processes in religious attachment disruptions. Unfortunately, the texts and discourses used did not provide evidence of the detachment phase which might have demonstrated the role of defensive processes as an important framework for theorizing inter-religious relations. In conclusion, attachment theory provides a platform to interpret acts of religious violence and terrorism, as seen in cases cited in this paper, as responses to attachment disruptions. This perspective allows us to argue that when recipients of attachment moves into defensive modes against an opposing group, they circle their wagons for protection from those perceived to be threats to their attachment bond, and then move to resolve their vulnerable feelings of fear and anxiety for losing a caregiver through their protest, despair, and detachment.

\section{Conclusion}

The paper provides theoretical insights on how the development of attachment transcends early childhood years and can become a lens through which to interpret the religious behaviour of adults. Attachment theory was used as an alternative theoretical framework for understanding the etiology of religious violence; thus, arguing that when a religious figure is experienced as a secure base and a safe haven, this salvation can generate into a cumulative allegiance and reciprocity toward such symbolic attachment figure. Hence, defensive 


\section{Victor Counted}

responses to attachment disruptions that threaten the relationship with the figure can be the precursor that increase the risk of adult religious psychopathology.

It is therefore proposed that religious violence can be reinterpreted as the by-product of attachment biological processes and a psychological problem, one that is internalised and created when a group or an individual, over time, disrupts the attachment process of another group. The organised defensive responses to this violation of attachment in the form of protest, despair, or detachment is a reasonable form of therapy, albeit a negative one, that is used as a reparative process for restoring confidence in the attachment bond. The starting point to resolving the issue of religious violence would be to amplify the role played by the human brain in creating toxic prejudices and expectations from which defensive responses are initiated. To this end, there is a need to identify the ways in which attachment disruptions are executed in the modern world in order to understand the extent to which we can conceptualise and problematize the conflicts that have now been labelled 'religious', 'political', and 'violent'.

\section{References}

Agbiboa, D.E. 2013. The Ongoing Campaign of Terror in Nigeria: Boko Haram versus the State. Stability: International Journal of Security and Development 2,3: 1-18.

Agbiboa, D.E. 2015. Why Boko Haram Exists: The Relative Deprivation

Perspective. African Conflict and Peacebuilding Review 3,1: 144-157.

Ainsworth, M.D.S. 1973. The Development of Infant-mother Attachment. In

Cardwell, B. \& H. Ricciuti (eds.): Review of Child Development Research.

Volume 3. Chicago: University of Chicago Press.

Ainsworth, M.D.S. 1989. Attachments beyond Infancy. American Psychologist 44: 709-716.

Ainsworth, M.S., M.C. Blehar, E. Waters \& T. Wall 1978. Patterns of Attachment: A Psychological Study of the Strange Situation. Hillsdale, NJ: Erlbaum.

al-Ansi, N. 2015. A Message Regarding the Blessed Battle of Paris. Yemen: al-Qaeda in Arabian Peninsula. 
Augustyn, B.D., T.W. Hall, D.C. Wang \& P.C. Hill 2016. Relational Spirituality: An Attachment-Based Model of Spiritual Development and Psychological Well-Being. Psychology of Religion and Spirituality.

BBC 2016, June 24. Eight Reasons Leave won the UK's Referendum on the

EU. Available at: www.bbc.com/news/uk-politics-eu-referendum36574526. (Accessed on 9 January 2017.)

Berman, S.L., M.J. Montgomery \& W.M. Kurtines 2004. The Development and Validation of a Measure of Identity Distress. Identity: An International Journal of Theory and Research 4,1: 1-8.

Berman, S.L., C.F. Weems \& T.R. Stickle 2006. Existential Anxiety in Adolescents: Prevalence, Structure, Association with Psychological Symptoms and Identity. Journal of Youth and Adolescence 35: 303-10.

Berzonsky, M.D. \& G.J. Neimeyer 1994. Ego Identity Status and Identity Processing Orientation: The Moderating Role of Commitment. Journal of Research in Personality 28,4: 425-35.

Bondarouk, T. \& H.J.M. Ruël 2004. Discourse Analysis: Making Complex Methodology Simple. In Leino, T., T. Saarinen \& S. Klein (eds.):

Proceedings of the 12th European Conference on Information Systems (ECIS). June 14-16 2004. Turku Finland.

Bowlby, J. 1958. The Nature of the Child's Tie to his Mother. International Journal of Psychoanalysis 39: 350-371.

Bowlby, J. 1973. Attachment and Loss. Volume 2: Separation. New York: Basic Books.

Bowlby, J. 1977. The Making and Breaking of Affectional Bonds. I: Aetiology and Psychopathology in the Light of Attachment Theory. II: Some Principles of Psychotherapy. British Journal of Psychiatry 130: 201-210 and 421-431.

Bowlby, J. 1982. Epilogue. In Parkes, C.M. \& J. Stevenson-Hinde (eds.): The Place of Attachment in Human Behavior. London \& New York: Tavistock.

Bowlby, J., J.D. Robertson \& D. Rosenbluth 1952. A Two-Year-Old Goes to Hospital. The Psychoanalytic Study of the Child 7,1:82-94.

Bowlby J. 1969. Attachment. Attachment and Loss: Volume 1. Loss. New York: Basic Books.

Boxel, J. 2011. Firebomb Attack on Satirical French Magazine. Financial Times 2 November. Available at: https://www.ft.com/content/75f87b240541-11e1-a3d1-00144feabdc0. (Accessed on 16 Janaury 2017.) 


\section{Victor Counted}

Brandt M.J., D.R. van Tongeren 2015. People both High and Low on Religious Fundamentalism are Prejudiced towards Dissimilar Groups. Journal of Personality and Social Psychology 112,1: 76-97.

Brandt M.J. \& C. Renya 2010. The Role of Prejudice and the Need for Closure in Religious Fundamentalism. Personality and Social Psychology Bulletin 36: 715-725.

Burke, D. 2015 Why Islam Forbids Images of Mohammed. BBC 9 January. Available at: http://edition.cnn.com/2015/01/07/living/islam-prophetimages/. (Accessed on 16 January 2017.)

Calhoun, C.J. 2002. Classical Sociological Theory. Oxford: Wiley-Blackwell. Campbell, E., G.R. Adams \& W.R. Dobson 1984. Familial Correlates of Identity Formation in Late Adolescence: A Study of the Predictive Utility of Connectedness and Individuality in Family Relations. Journal of Youth and Adolescence 13,6: 509-25.

Cicirelli, V.G. 1991a. Attachment Theory in Old Age: Protection of the Attached Figure. In Pillemer, K. \& K. McCartney (eds.): Parent-child Relations across the Life Span. Hillsdale, NJ: Erlbaum.

Cicirelli, V.G. 1991b. Life Span Attachment Theory as an Explanation of Children's Help to Frail Elderly Parents. In Montada, L. \& H.W.

Bierhoff (eds.): Altruism in Social Systems. Toronto: Hogrefe.

Cicirelli, V.G. 2014. God as the Ultimate Attachment Figure for Older Adults. Attachment and Human Development 6,4: 371-388.

Counted, V. 2016a. The Psychology of Youth Faith Formation: A Caregiving Faith? Journal of Youth and Theology 15,2:146 - 172.

Counted, V. 2016b. God as an Attachment Figure: A Case Study of the God Attachment Language and God Concepts of Anxiously Attached Christian Youths in South Africa. Journal of Spirituality in Mental Health 18,4:316346.

Counted, V. \& F. Watts 2017. Place Attachment in the Bible: The Role of Sacred Places in Religious Life. Journal of Psychology and Theology.

Ellison, C.G., M. Bradshaw, K.J. Flannelly \& K.C. Galek 2015. Prayer, Attachment to God, and Symptoms of Anxiety-Related Disorders among U.S. Adults. Sociology of Religion 76,1: 140-143.

Erikson, E. 1956. The Problem of Ego Identity. Journal of the American Psychoanalytic Association 4: 56-121.

Ferm, V. 1945. The Encyclopedia of Religion. Secaucus, NJ: Poplar. Gallup, G., Jr., \& S. Jones 1989. One Hundred Questions and Answers: 
Religion in America. Princeton, NJ: Princeton Religious Research Center. Georgaca, E. \& E. Avdi 2011. Discourse Analysis. In Harper, D. \& A.R. Thompson (eds.): Qualitative Research Methods in Mental Health and Psychotherapy: A Guide for Students and Practitioners. New York: John Wiley \& Sons.

Giddens, A. 1990. The Consequences of Modernity. Cambridge: Polity Press. Granqvist, P. \& B. Hagekull 1999. Religiousness and Perceived Childhood Attachment: Profiling Socialized Correspondence and Emotional Compensation. Journal for the Scientific Study of Religion 38: 254-273. Granqvist, P., M. Mikulincer, V. Gewirtz \& P.R. Shaver 2012. Experimental Findings on God as an AF: Normative Processes and Moderating Effects of Internal Working Models. Journal of Personality and Social Psychology 103:804-818.

Granqvist, P., B. Hagekull \& T. Ivarsson 2012. Disorganised Attachment Promotes Mystical Experiences via a Propensity for Alterations in Consciousness (Absorption). International Journal for the Psychology Religion 22:180-197.

Granqvist, P., M. Mikulincer \& P.R. Shaver 2010. Religion as Attachment: Normative Processes and Individual Differences. Personality and Social Psychology Review 14: 49-59.

Granqvist, P., C. Ljungdahl \& J.R. Dickie 2009. God is Nowhere, God is Now Here: Attachment Activation, Security of Attachment, and Perceived Closeness to God among 5-7-year-old Children from Religious and Nonreligious Homes. Attachment and Human Development 9: 55-71.

Granqvist, P. \& I.A. KirkpatrickL 2016. Attachment and Religious Representations and Behavior. In Cassidy, J. \& P.R. Shaver (eds.): Handbook of Attachment: Theory, Research, and Clinical Applications. $3^{\text {rd }}$ Edition. New York: Guilford.

Gruber, C. 2015. The Koran does not Forbid Images of the Prophet. Newsweek. Available at: http://europe.newsweek.com/koran-does-not-forbid-imagesprophet-298298?rm=eu. (Accessed on 16 January 2017.)

Hall T.W., A. Fujikawa, Sarah R. Halcrow \& P.C. Hill 2009. Attachment to God and Implicit Spirituality: Clarifying Correspondence and Compensation Models. Journal of Psychology and Theology 37: 227-242.

Hart, J.T., A. Limke \& P.R. Budd 2010. Attachment and Faith Development. Journal of Psychology and Theology 38,2:122-128.

Howard, K., A. Martin, L.J. Berlin \& J. Brooks-Gunn 2011. Early Mother- 
Child Separation, Parenting, and Child Well-Being in Early Head Start Families. Attachment and Human Development 13,1: 5-26.

Huntington, S. 1996. The Clash of Civilizations and the Remaking of World Order. New York: Simon \& Schuster.

Irish, J. 2014. Nigerian President: Boko Haram is West Africa's Al Qaeda. Reuters. Available at: http://www.businessinsider. com/r-boko-haram-iswest-africas-al-qaeda-says-nigerian-president-2014-17. (Accessed on 16 January 2017.)

Isa, M.K. 2010. Militant Islamist Groups in Northern Nigeria. In Okumu, W.

\& A. Ikelegbe (eds.): Militias, Rebels and Islamist Militants: Human

Security and State Crises in Africa. Pretoria, South Africa: Institute for Security Studies.

Johnson, M.K., W.C. Rowatt \& J.P. LaBouff 2012. Religiosity and Prejudice

Revisited: In-group Favoritism, Out-group Derogation, or Both? Psychology of Religion and Spirituality 4,2: 154-168.

Jones, T. 2010. Pastor Terry Jones wants to Burn Quran on 9/11. Available at: https://youtu.be/HqtrYRaeOTM. (Accessed on 25 May 2017.)

Kashima, Y. 2016. Culture and Psychology in the $21^{\text {st }}$ Century: Conceptions of Culture and Person for Psychology Revisited. Journal of Cross-Cultural Psychology 47: 4-20.

Khazan, O. 2012. Charlie Hebdo Cartoons Spark Debate over Free Speech and Islamophobia. The Washington Post 19 September. Available at: https://www.washingtonpost.com/blogs/blogpost/post/charlie-hebdocartoons-spark-debate-over-free-speech-and-islamophobia/2012/09/ 19/4b3ba988-026b-11e2-9b24-ff730c7f6312_blog.html?utm_term=. 8fb1639789a3. (Accessed on 16 January 2017.)

Kirkpatrick, L.A. 1992. An Attachment-theory Approach to the Psychology of Religion. The International Journal for the Psychology of Religion 2: 3 28.

Kirkpatrick, L. A. 1998. God as a Substitute Attachment Figure: A Longitudinal Study of Adult Attachment Style and Religious Change in College Students. Personality and Social Psychology Bulletin 24: 961973.

Kobak, R, K. Zajac \& S.D. Madsen 2016. Attachment Disruptions, Reparative Processes, and Psychopathology: Theoretical and Clinical Implications. In Cassidy, J. \& P.R. Shaver (eds.): Handbook of Attachment: Theory, Research, and Clinical Applications. New York: Guilford Press. 
Lapsley, K.D., K. Rice \& D. FitzGerald 1990. Adolescent Attachment, Identity, adjustment to College: Implications for the Continuity of Adaptation Hypothesis. Journal of Counselling and Development 68: 561-565.

Leonard, K.C., K.V. Cook, C.J. Boyatzis, C.N. Kimball, \& K.S. Flanagan 2013. Parent-Child Dynamics and Emerging Adult Religiosity: Attachment, Parental Beliefs, and Faith Support. Psychology of Religion and Spirituality 5,1: 5-14.

Levin, B. \& K. Grisham 2016. Hate Crime in the United States: 20 State Compilation Data. San Bernardino: Center for the Study of Hate and Extremism, California State University.

Liotti, G. 2004. Trauma, Dissociation, and Disorganized Attachment: Three Strands of a Single Braid. Psychotherapy: Theory, Research, Practice, Training 41: 472-486.

Lowenstein, L.F. 2007. Parental Alienation: How to Understand and Address Parental Alienation Resulting from Acrimonious Divorce or Separation. Dorset, UK: Russell House Publishing.

Main, M., \& J. Solomon 1986. Discovery of a New, Insecure-disorganized/ Disoriented Attachment Pattern. In Yogman, M. \& T.B. Brazelton (eds.): Affective Development in Infancy. Norwood, NJ: Ablex.

Main, M. \& J. Solomon 1990. Procedures for Identifying Infants as Disorganised/ Disoriented during the Ainsworth Strange Situation. In Greenberg, M.T., D. Cicchetti \& E.M. Cummings (eds.): Attachment in the Preschool Years. Chicago, IL: University of Chicago Press.

Mickelson, K.D., R.C. Kessler \& P.R. Shaver 1997. Adult Attachment in a Nationally Representative Sample. Journal of Personal Social Psychology 73,5:1092-106.

Murray, D. 8 France even more Fractured after the Charlie Hebdo Rampage. CBC News. January 2015. Available at: http://www.cbc.ca/news/world/ france-even-more-fractured-after-the-charlie-hebdo-rampage-1.2893262. (Accessed on 16 January 2017.)

Mustapha, A.R. 2014. Understanding Boko Haram. In Abdul Raufu Mustapha (ed.): Sects \& Social Disorder: Muslim Identities \& Conflict in Northern Nigeria. London: James Currey.

Neumayer, E. \& T. Plumper 2009. International Terrorism and the Clash of Civilizations. British Journal of Political Science 39,4: 711-734.

Pate, A. 2015. Boko Haram: An Assessment of Strengths, Vulnerabilities, and Policy Options. Maryland: National Consortium for the Study of Terror- 


\section{Victor Counted}

ism and Responses to Terrorism, University of Maryland.

Prior, V. \& D. Glaser 2006. Understanding Attachment and Attachment Disorders: Theory, Evidence and Practice. London \& Philadelphia: Jessica Kingsley Publishers.

Ruiz, D.M. 2013. Five Levels of Attachment: Toltec Wisdom for the Modern World. San Antonio: Hierophant Publishing.

Salkida, A. 2009. Sect Leader Vows Revenge. Daily Trust. Available at: http://wwrn.org/articles/31419/?\&place=nigeria. (Accessed on 16 January 2017.)

Samuel, H. 2012. France to Close Schools and Embassies Fearing Mohammed Cartoon Reaction. The Telegraph 19 September. Available at: http://www.telegraph.co.uk/news/worldnews/europe/france/9553722/Fra nce-to-close-schools-and-embassies-fearing-Mohammed-cartoonreaction.html. (Accessed on 16 January 2017.)

Saroglou, V. 2016. Intergroup Conflict, Religious Fundamentalism, and Culture. Journal of Cross-Cultural Psychology 47,1: 33-41.

Solomon, J. \& C. George 2011. Disorganised Attachment and Caregiving. New York: Guilford Press.

Soltis, A. 1983. The Art of Defense in Chess. Pennsylvania: David McKay Publications.

Sroufe, L.A. E. \& Waters 1977. Attachment as an Organizational Construct. Child Development 48: 1184-1199.

Umar, S. 2011. The Discourses of Salafi Radicalism and Salafi CounterRadicalism in Nigeria: A Case-Study of Boko Haram. Evanston, IL: Northwestern University.

Walker, A. 2012. What is Boko Haram? Washington, DC: United States Institute of Peace.

Waters, E. \& E.M. Cummings 2000. A Secure Base from which to Explore Close Relationships. Child Development 49:164-172.

Weiss, R.S. 1986. Continuities and Transformations in Social Relationships from Childhood to Adulthood. In Hartup, W.W. \& Z. Rubin (eds.): On Relationships and Development. Hillsdale, NJ: Erlbaum.

Williams, R.J. \& F.N. Watts 2014. Attributions in a Spiritual Healing Context:

An Archival Analysis of a 1920s Healing Movement. Journal for the Scientific Study of Religion 53: 90-108.

Wilson, E. 2016, The Problem is Religion - but not in the Way we Think. The Religion Factor March 23. Available at: https://religionfactor.net/2016/ 
03/23/the-problem-is-religion-but-not-in-the-way-we-think. (Accessed on 08 January 2017.)

Winnicott, D. 1953. Transitional Objects and Transitional Phenomena. In Through Paediatrics to Psycho-analysis. London: Hogarth Press.

Vinocur, N. September, 2012. Cartoons in French Weekly Fuel Mohammad Furor. Reuters. Available at: www.reuters.com/article/us-protests-franceidUSBRE88IOBU20120919. (Accessed on 31 May 2017.)

Victor Counted

School of Social Science and Psychology Western Sydney University Australia and Faculty of Theology Stellenbosch University Stellenbosch

South Africa v.counted@westernsydney.edu.au 